Transactions of the Karelian Research Centre of the Russian Academy of Sciences

No. 7. 2021. P. 89-99

DOI: $10.17076 /$ them 1413
Труды Карельского научного центра РАН

№ 7. 2021. C. 89-99

УДК 591.481.3:599.742.1

\title{
MORPHOLOGY AND MINERAL COMPOSITION OF PINEAL GLAND CONCRETIONS IN VULPES LAGOPUS L., 1758 (MAMMALIA: CARNIVORA)
}

\author{
S. N. Kalinina ${ }^{1}$, S. Yu. Chazhengina ${ }^{2}$, V. A. llyukha ${ }^{1}$, S. A. Svetov', \\ E. A. Khizhkin ${ }^{1}$ \\ ${ }^{1}$ Institute of Biology, Karelian Research Centre, Russian Academy of Sciences, Petrozavodsk, Russia \\ ${ }^{2}$ Institute of Geology, Karelian Research Centre, Russian Academy of Sciences, Petrozavodsk, Russia
}

\begin{abstract}
Mammalian pineal gland is known to often contain calcified concretions (brain sand, corpora arenacea, acervuli, concrements) with understudied biological significance, mineral and chemical compositions. Previous studies reported about the chemistry, shape, size and structure of these biominerals from human and rodent pineal gland. This study addresses the morphology, mineral and chemical composition of calcified concretions in pineal gland of blue fox Vulpes lagopus L. (Mammalia: Carnivora). We used routine histological methods as well as scanning electron microscopy coupled with energy-dispersive detector and Raman spectroscopy. The results suggest that the process of pineal gland mineralization is most likely not age-related. Our data concerning the location and mineral composition of calcium concretions in blue fox pineal gland are in agreement with those obtained by other researchers for rodent and human pineal glands. Calcified concretions were located in pineal gland capsule, protruding septae, and parenchyma. Two morphological types of concrements were distinguished, including mulberry-like and irregular elongated structures. The acervuli of mulberry-like structure contained hydroxylapatite and calcite, and the irregular elongated aggregates were composed of hydroxylapatite only. The latter has not been previously recorded from calcified concretions in mammals. These findings give the first insight into the morphology, mineral and chemical composition of calcium concrements in pineal gland of blue fox.
\end{abstract}

Ke yw ord s: calcified concretions; calcite; hydroxylapatite; pineal gland; Vulpes lagopus L.
С. Н. Калинина,
С. Ю. Чаженгина,
В. А. Илюха,
С. А. Светов,
Е. А. ХИЖКИН. МОРФОЛОГИЯ И МИНЕРАЛЬНЫЙ СОСТАВ КОНКРЕЦИЙ ШИШКОВИДНОЙ ЖЕЛЕЗЫ У ПЕСЦА VULPES LAGOPUS L., 1758 (MAMMALIA: CARNIVORA)

Известно, что шишковидная железа (эпифиз мозга) млекопитающих часто содержит кальцинированные конкременты (мозговой песок, corpora arenacea, acervuli, конкременты), биологическое значение, минеральный и химический состав которых не полностью изучены. Ранее сообщалось о химическом составе, форме, размере и структуре этих биоминералов эпифиза человека и грызунов. Настоящее исследование посвящено морфологии, минеральному и химическому составу кальцинированных конкрементов в шишковидной железе песца Vulpes lagopus L. 
(Mammalia: Carnivora). Использовали стандартные гистологические методы, а также сканирующую электронную микроскопию в сочетании с энергодисперсионным детектором и рамановской спектроскопией. Результаты свидетельствуют о том, что процесс минерализации шишковидной железы, скорее всего, не связан с возрастом. Наши данные о расположении и минеральном составе конкреций кальция в шишковидной железе песца согласуются с данными, полученными другими исследователями на шишковидной железе грызунов и человека. Кальцинированные конкременты располагались в капсуле, перегородках и паренхиме шишковидной железы. Выделили два морфологических типа конкрементов: виноградоподобные и неправильной удлиненной формы. Конкременты виноградоподобной структуры включали гидроксилапатит и кальцит, а агрегаты неправильной вытянутой формы состояли только из гидроксилапатита. Последний ранее не был обнаружен в кальцинированных конкрециях млекопитающих. Результаты дают первое представление о морфологии, минеральном и химическом составе конкрементов кальция в шишковидной железе песца.

Ключевые слова: кальцинированные конкреции; кальцит; гидроксилапатит; шишковидная железа; Vulpes lagopus L.

\section{Introduction}

Biogenic minerals, or biominerals, are the composite materials containing an organic matrix and nano- or micro-scale amorphous or crystalline minerals [Gilbert et al., 2005]. In mammalian organism, the biomineral composite materials include bone, dentine, enamel, otoliths, pineal concrements, etc. The latter are also called 'brain sand' (corpora arenacea, calcified concretions, acervuli), which is often detected in pineal glands of humans [Bocchi, Valdre, 1993; Maślińska et al., 2010; Kim et al., 2012] and many mammalian species [Lewinski et al., 1983; Vígh et al., 1998; Bulc et al., 2010].

Two morphological types of concrements are distinguished under light microscope. The first type consists of single concretions with a concentric laminar structure marked by light and dark layers, while the second one is represented by a mulberry-like structure consisting of a large number of interconnected nodules [Kim et al., 2012]. It is noteworthy that both types often coexist within a pineal gland [Kim et al., 2012]. In mammals, pineal concretions reach a size of 2-3 $\mu \mathrm{m}$, forming conglomerates of up to $1 \mathrm{~mm}$ or more [Vigh et al., 1998; Bulc et al., 2010; Kim et al., 2012].

The composition of concrements is heterogeneous and includes inorganic and organic components [Krstić, 1976; Kodaka et al., 1994]. The former generally comprises hydroxyapatite [Bocchi, Valdre, 1993], calcite [Bacconier, Lang, 2004], fluorite [Luke, 2001] and aragonite [Tofail et al., 2019], while the latter includes glucosaminoglycans and their complexes with proteins, pineal hormones, structures of membranes, and the cytoplasmic matrix of pinealocytes [Vígh et al., 1998]. Hydroxylapatite has not so far been reported from mammalian pineal gland. Chemical methods show the presence of a large amount of $\mathrm{Ca}$ and $\mathrm{P}$ [Bocchi, Valdre, 1993] and traces of S, Mg, N, Fe, Zn, and $\mathrm{Cu}$ in concrements [Kodaka et al., 1994; Nakamura et al., 1995].

Pineal concretions have long been studied using histochemical methods [Humbert, Pévet, 1992; Bulc et al., 2010], transmission and scanning electron microscopy in combination with $\mathrm{X}$-ray microanalysis [Kodaka et al., 1994; Nakamura et al., 1995; Baconnier, Lang, 2004; Kim et al., 2012] as well as a number of label-free surface characterization techniques such as X-ray Photoelectron Spectroscopy (XPS) and Energy Dispersive X-ray Spectroscopy (EDX) [Tofail et al., 2019]. However, these studies are few and usually based on the application of one or two analytical methods, which cannot provide a comprehensive description of the morphology, mineral and chemical composition of the solid-phase pineal concretions. Hence, it is of critical importance to use a complex and multidisciplinary approach to studying the properties of pineal concrements. We employed routine histological methods, as well as scanning electron microscopy coupled with energy-dispersive detector and Raman spectroscopy to study brain sand.

Currently, pineal calcification is the one of the most intriguing phenomena, since the questions of its physiological relevance for the organism and the sources of its formation are yet unresolved. The formation of concrements has been associated with aging, reproductive status, ethnicity, geographic location, gender, and environmental factors such as altitude and exposure to sunlight [Zimmerman, Bilaniuk, 1982; Lewinski et al., 1983; Schmid, 1993; Mori et al., 2003; Turgut et al., 2008; Admassie, Mekonnen, 2009; Bulc et al., 2010]. The pineal gland has one of the high- 
est calcification rates in the human body [Whitehead et al., 2015]. In a study of 12,000 healthy subjects, it was observed that $71.6 \%$ of them had pineal gland calcifications. Large amounts of evidence suggest that the pineal calcification is associated with human pathological disorders (Alzheimer's disease, schizophrenia, etc.) and aging [review by Tan et al., 2018]. Hence, the study of the morphogenesis of pineal biominerals is of high relevance. The mineralization of mammalian pineal gland may be species-specific. For example, pineal concrements are more often revealed in species such as Mongolian gerbil (Meriones unguiculatus, Muridae, Rodentia) [Lewinski et al., 1983] or in humans [Turgut et al., 2008; Admassie, Mekonnen, 2009]. To date, blue fox (Vulpes lagopus) is the only Canidae species (Mammalia: Carnivora) whose pineal gland has been found to contain the concretions [Bulc et al., 2010].

It is thus of high interest to investigate the morphology, mineral and chemical properties of pineal gland concretions to understand in the near future the reasons for their formation as well as their possible biological significance. So, the aim of this study was to analyze the morphology, mineral and chemical composition of pineal calcium concretions in blue fox.

\section{Material and methods}

The study was carried out using the equipment of the Core Facility of the Karelian Research Centre of the Russian Academy of Sciences and according to EU Directive 2010/63/EU for animal experiments with special permission from the Local Ethics Committee of the Institute of Biology.

\section{Animals and material collection}

Juveniles $(n=4)$ and adults $(n=6)$ of blue fox (V. lagopus L., 1758) (Mammalia: Carnivora) were used. The animals were reared in a fur farm in individual, outdoor cages. They were fed in accordance with the nutritional regime for fur-bearing animals with free access to water. The animals were sacrificed between 8 a. m. and 9 a. m. in December (period of sexual rest; photoperiod $07 \mathrm{~h}$ light : $17 \mathrm{~h}$ dark) in line with the approved procedure for fur animal farms. Pineal glands were removed immediately after skinning.

\section{Histology and light microscopic examination}

After removal, the pineal glands were immediately fixed by immersion in $10 \%$ neutral buffered formalin at room temperature for histological preparations. The fixed glands were dehydrated in ascending series of alcohol grades, cleared in xylene, then embedded in paraffin wax and sectioned with a thickness of $5 \mu \mathrm{m}$ in the coronal or sagittal planes. The sections were then stained with Ehrlich's haematoxylin and counterstained with eosin (H\&E) and Masson-Goldner to visualize connective tissue. The stained sections were then mounted in distyrene plasticizer and observed under light microscope AxioScope. A1 (Zeiss, Germany). The images were made using video camera AxioCam MRc 5 (Zeiss, Germany) connected to the microscope, and image-processing system AxioVision (Zeiss, Germany).

\section{Concrement isolation from pineal gland}

Calcified concretions were extracted from the pineal glands of 5 blue fox adults using a procedure described in a study by Baconnier and Lang [2004]. Five pineal glands with the total mass of $0.5 \mathrm{~g}$ were placed in a microcentrifuge tube. $1.5 \mathrm{ml}$ of $2.5 \%$ sodium hypochlorite solution was added to the brain substance and sonicated for $10 \mathrm{~min}$. The sample was allowed to settle for $1 \mathrm{~min}$ and then the supernatant liquid was removed to a second microcentrifuge tube and centrifuged at approximately $9000 \mathrm{~g}$ for $1 \mathrm{~min}$. Then the sample was immediately washed twice with $95 \%$ ethanol and then resuspended in approximately $50 \mathrm{ml}$ of $100 \%$ ethanol. From the ethanol solution, the specimens were deposited on glass plate. It is noteworthy that the samples did not come in contact with solutions containing calcium ions.

\section{Scanning electron microscopy (SEM)}

Scanning electron microscopy was applied to study the morphology and composition of calcified concretions. The experiments were carried out using unstained sections and extracts of pineal glands. The analysis was facilitated by a VEGA II LSH scanning electron microscope (Tescan, Czech Republic) with an energy dispersive detector INCA Energy 350 (Oxford Instruments). The setup of the SEM study was the following: W-cathode, a voltage of $20 \mathrm{~kW}$, and a spectrum setting time at analytical points of $90 \mathrm{sec}$ in a standard experiment. For the SEM observations, the specimens were covered with carbon or beryllium film.

\section{Raman spectroscopy}

Raman analysis of the calcified concretions was carried out using a dispersive Nicolet Almega XR Raman spectrometer with a green laser (532 nm, Nd-YAG). The spectra were collected on unstained sections and extracts of pineal glands at $2-\mathrm{cm}^{-1}$ 
spectral resolution. The spectrometer was calibrated before each analytical session by 'zero-point' centering and by analyzing an Si-standard with a characteristic Si Raman band at $520.4 \mathrm{~cm}^{-1}$. A confocal microscope with a $50 \times$ objective lens was used to focus the excitation laser beam on the sample and to collect the Raman signal from a 2- $\mu \mathrm{m}$ diameter area. The final laser power was about 5-10 $\mathrm{mW}$ at the sample surface. Raman spectra were acquired in the $200-4000 \mathrm{~cm}^{-1} \mathrm{spec}-$ tral region, with $30 \mathrm{~s}$ exposition time. Raman spectral data of calcified concretions, such as band position and full width at half maximum (FWHM), were determined using OMNIC software with a Gaussian/Lorentzian function.

\section{Results}

\section{Pineal morphology in blue fox}

Pineal gland of blue fox is classified into $A$ or $A B$ types according to Vollrath's classification [Vollrath, 1981] and displays large individual variability in shape and size. Generally speaking, the pineal is a conical organ (up to 5-6 mm long and 3-4 $\mathrm{mm}$ wide) with or without invagination on the surface and sometimes divided into two parts by connective tissue fibers. The pineal gland is surrounded by a pial capsule. Pial cells are flattened connective tissue cells derived from the mesoderm and with some cells from the neural crest. Glandular parenchyma comprises more numerous pinealocytes, cells with large nuclei of oval or round shape, less abundant glial cells, probably astrocytes, with highly heterochromatic (strongly stained) small nuclei, fibroblasts, blood vessels, reticular and collagen fibers.

Pineal acervuli were round, oval or irregular in shape, and located in capsule, septae and parenchyma (Fig. 1). At the light microscopic level, they were observed in both juveniles and adults, but not in all individuals. Some glands contained numerous deposits of different sizes, whereas others had only few acervuli.

In the sections stained with H\&E, concrements were colored purple (Fig. 1, a-d). Some of them were dark without clear evident laminar structure, others were light-stained and seemed to be hollow, and the third group had a marked laminar structure with alternative layers of light- and dark-stained rings. In samples stained according to the Masson-Goldner method, acervuli were colored pink, light green or both (Fig. 1, e, f). In some concrements several layers or the point of calcification initiation were black. In the immediate vicinity of acervuli denegerated cells, fibroblasts and collagen fibers were often observed.

\section{Micromorphological features and chemical composition of pineal concretions}

SEM observations are the most important in this study permitting to describe the morphology of calcified concretions in detail. Among concentrates from pineal gland, two types of concrements were distinguished according to their morphology. The first type is characterized by ellipsoidal to approximately spherical shape and size in a range of 7-10 $\mu \mathrm{m}$ (Fig. 2, a, b). This morphology is similar to the so-called "mulberry-like" structure reported for human pineal glands [Krstić, 1976; Kodaka et al., 1994; Baconnier, Lang, 2004; Kim et al., 2012]. The second type of concrements was elongate irregular-shaped particles with $1: 2$ ratio between sides in two directions (Fig. 2, c, d). They were larger, up to $25 \mu \mathrm{m}$. This type of concretions was the most abundant in the observed samples. It should be emphasized that no single crystals were revealed in the studied pineal glands, and both varieties of calcified concretions were represented by aggregates of irregular or elongated particles within $<1-6 \mathrm{~mm}$ in size.

EDS analysis was carried out to determine the composition of the concrements. The SEM images of acervuli and the corresponding EDS results are shown in Figure 3. The principal elements identified were calcium, phosphorous, carbon, and oxygen. We were unable to quantify carbon and oxygen because of organic matter presence in the sample. Moreover, additional oxygen content might come from the glass base of the sample. The $\mathrm{Na}, \mathrm{Mg}$ and $\mathrm{Si}$ impurities were also due to the glass base. Microprobe analysis revealed two types of calcified concretions. The first group was apatite (Fig. 3, 1a, 2a). The $\mathrm{Ca} / \mathrm{P}$ ratio was similar in the two morphological types of concrements, and varied within 1.25-1.76 with an average of 1.36. The chemical composition of the second group of calcified concretions (Fig. 3, 1b, 2b) included carbon and oxygen, which can be interpreted as calcium carbonate or oxalate.

\section{Spectroscopic features of pineal concretions}

Raman spectroscopy is a widely-recognized technique for the identification and crystallochemical interpretation of biominerals, including apatite from bone [Timlin et al., 1999; Carden, Morris, 2000; Thomas et al., 2011; Pasteris et al., 2014] and pineal gland [Baconnier, Lang, 2004]. The Raman spectrum of hydroxylapatite is defined by the occurrence of narrow bands at 588, 960 and $1044 \mathrm{~cm}^{-1}$, which come from the symmetric $\mathrm{P}-\mathrm{O}$ stretch for $\mathrm{PO} 4$ tetrahedra [Pasteris et al., 2014]. Additionally, the Raman spectrum of hydro- 


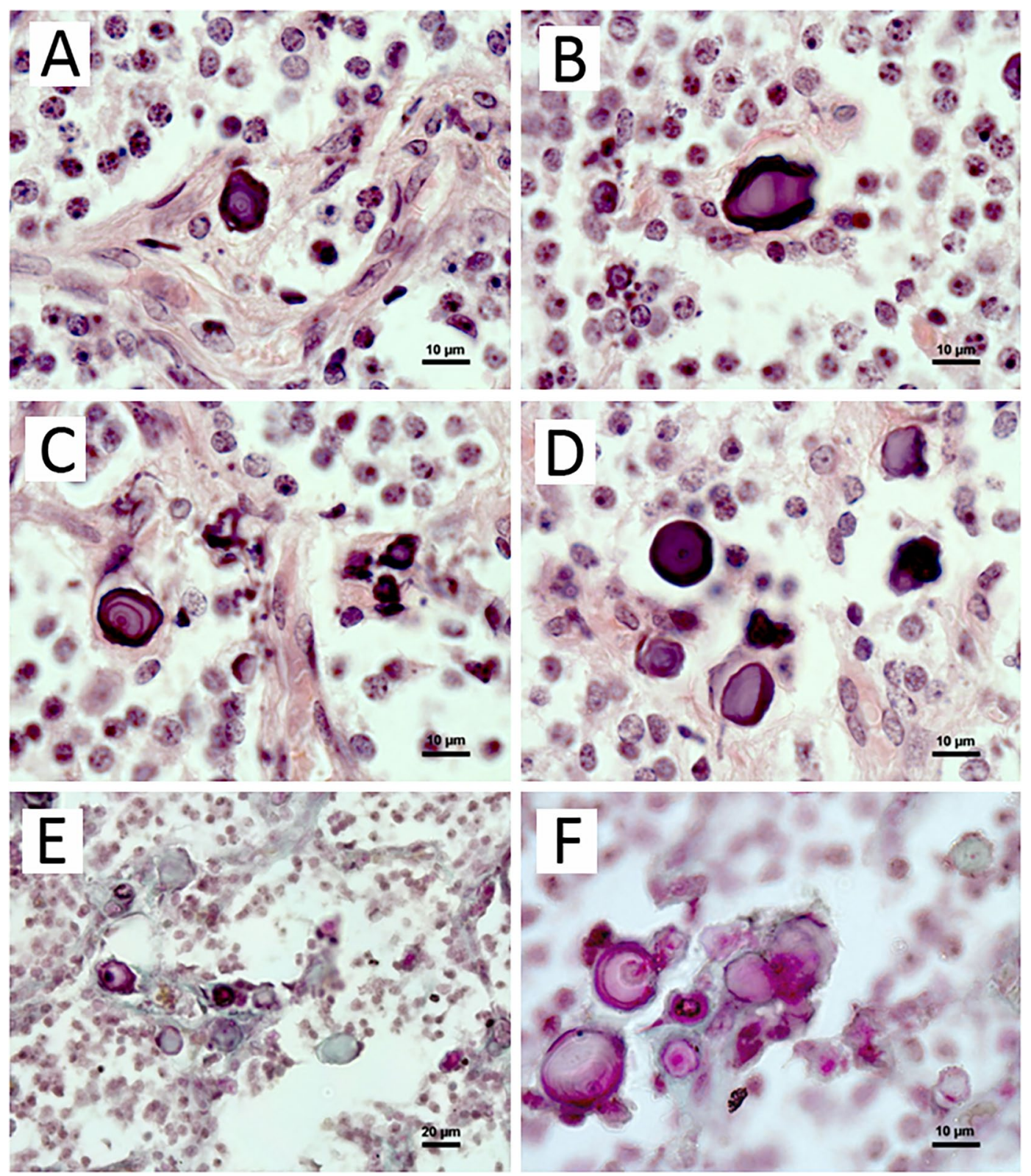

Fig 1. Calcified concretions in the pineal gland of adult blue fox.

Structure: (a), (c), (f) are laminar concretions with alternative layers of light- and dark-stained rings; (b) are hollow-like ones; (d), (e), (f) are acervuli without clear laminar structure.

(a-d) H\&E, (e-f) Masson-Goldner staining. Scale bar is $10 \mu \mathrm{m}$

xylapatite displayed a narrow band at $\sim 3572 \mathrm{~cm}^{-1}$, which corresponded to the O-H stretch for hydroxyl in the channel site of apatite structure and broad band centered at about $3400 \mathrm{~cm}^{-1}$, indicative of molecular water [Pasteris et al., 2014]. The Raman spectra of calcium concretions were consistent with hydroxylapatite, although the spectra were "poor" compared to the synthetic one (Fig. 4). Only two peaks were detected in the Raman spectra of studied specimens, which corresponded to the symmetric $\mathrm{P}-\mathrm{O}$ stretch for $\mathrm{PO}_{4}$ tetrahedra. The most intensive peak of apatite detected in the Raman spectra of the studied speci- mens was in the $958 \mathrm{~cm}^{-1}$ position and had a band width of $\mathrm{FWHM}=18 \mathrm{~cm}^{-1}$. The low-intensity broad band was detected at $1056 \mathrm{~cm}^{-1}$. It should probably be attributed to the combination of apatite band at $1044 \mathrm{~cm}^{-1}$ and carbonate band at $1075 \mathrm{~cm}^{-1}$ [Karampas, Kontoyannis, 2013]. Additionally, Raman spectra of calcified concretions displayed two broad bands centered at 3476 and $3700 \mathrm{~cm}^{-1}$, mainly corresponding to adsorbed and crystallographically incorporated water (Fig. 4). No bands indicative of carbonate substitution for phosphate in apatite were recorded in the Raman spectra of the calcified concretions. However, it has been 

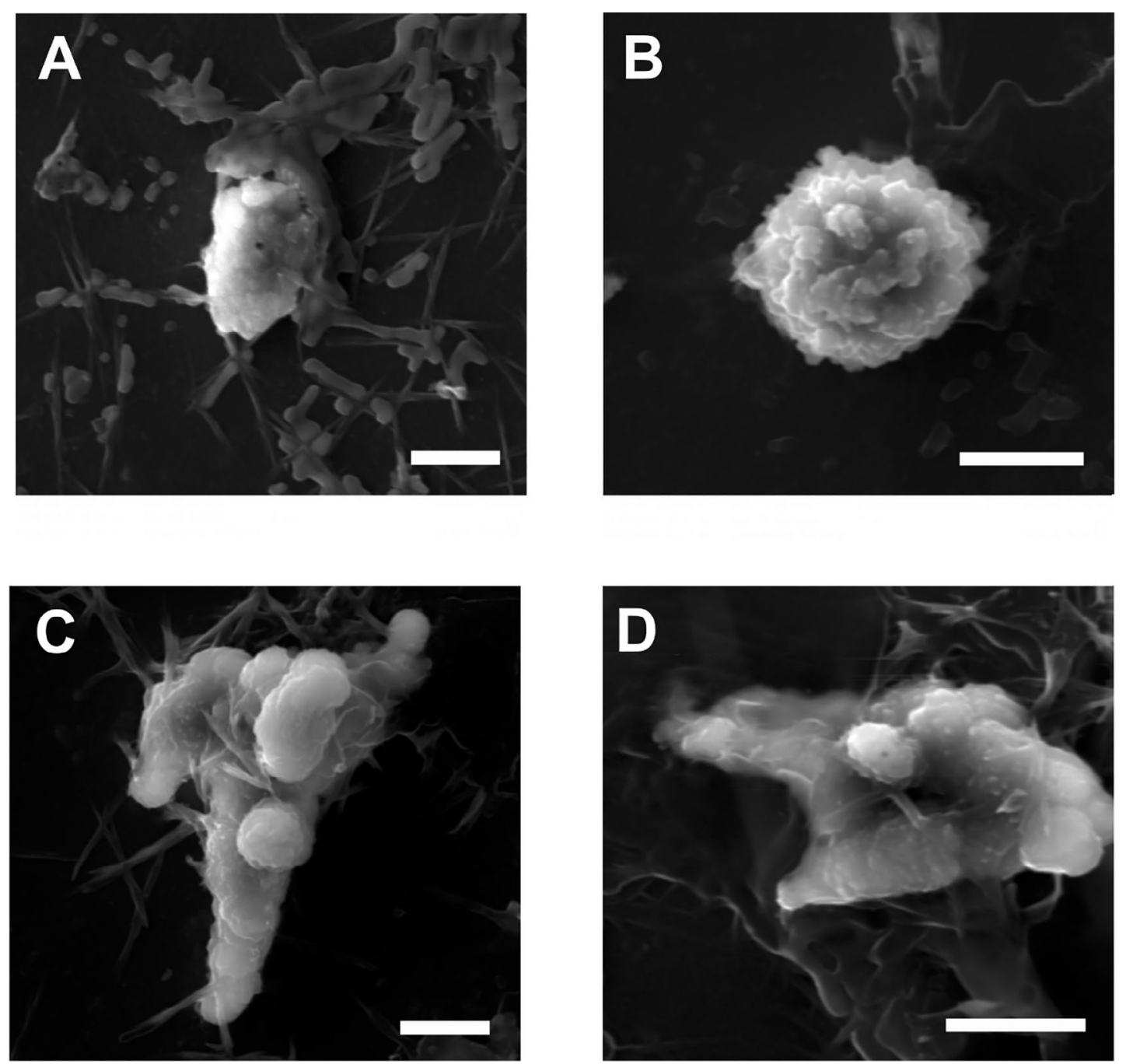

Fig. 2. Secondary electron (SE) images of mulberry-like $(a, b)$ and irregular elongate $(c, d)$ pineal gland concrements. Scale bar is $5 \mu \mathrm{m}$

established [Thomas et al., 2011] that the position and width (FWHM) of the band correspond to the symmetric stretching mode $\mathrm{v}_{1}-\mathrm{PO}_{4}$ correlated with the hydroxylapatite composition, including the carbonate content. Synthetic hydroxylapatite without impurities was characterized by Raman parameters including the Raman frequencies of $960 \mathrm{~cm}^{-1}$ and $\mathrm{FWHM}=9.2 \mathrm{~cm}^{-1}$ [Thomas et al., 2011]. Hydroxylapatite from the concrements was characterized by a slightly lower band position $\left(958 \mathrm{~cm}^{-1}\right)$ and a significantly higher band width $\mathrm{FWHM}=18 \mathrm{~cm}^{-1}$. These spectroscopic features are specific to apatite with the carbonate substitution in $\mathrm{PO}_{4}$ tetrahedra [Thomas et al., 2011]. Another evidence of phosphate substitution by carbonates comes from the relatively high total water content marked by broad bands at around $3500 \mathrm{~cm}^{-1}$ detected for the calcified concretions. According to Pasteris et al. [2014], the increase in carbonate concentration within the apatite is correlated with an increase in spectroscopically recorded total water content. Therefore, the Raman data suggest that the studied calcified concretions are composed of the carbonated hydroxylapatite. Hydroxylapatite was recognized in a majority of the studied calcified concretions. It was represented by both "mulberry-like" structures and elongate irregular-shaped particles with the size ca. 3-25 mm.

Raman spectroscopy was used to distinguish between calcium carbonate or oxcalate minerals in the calcified concretions of blue fox pineal gland. Raman spectroscopic data revealed that the calcified concretions composed of calcium and carbon were represented only by calcite. It was identified by the characteristic bands at 712 and $1088 \mathrm{~cm}^{-1}$ (Fig. 5). Calcite was found in all the studied calcified concretions. In the calcified concretions composed of both calcite and hydroxylapatite, the number of calcite grains appeared to be higher than the number of hydroxylapatite grains. In contrast to hydroxylapatite, calcite was represented 

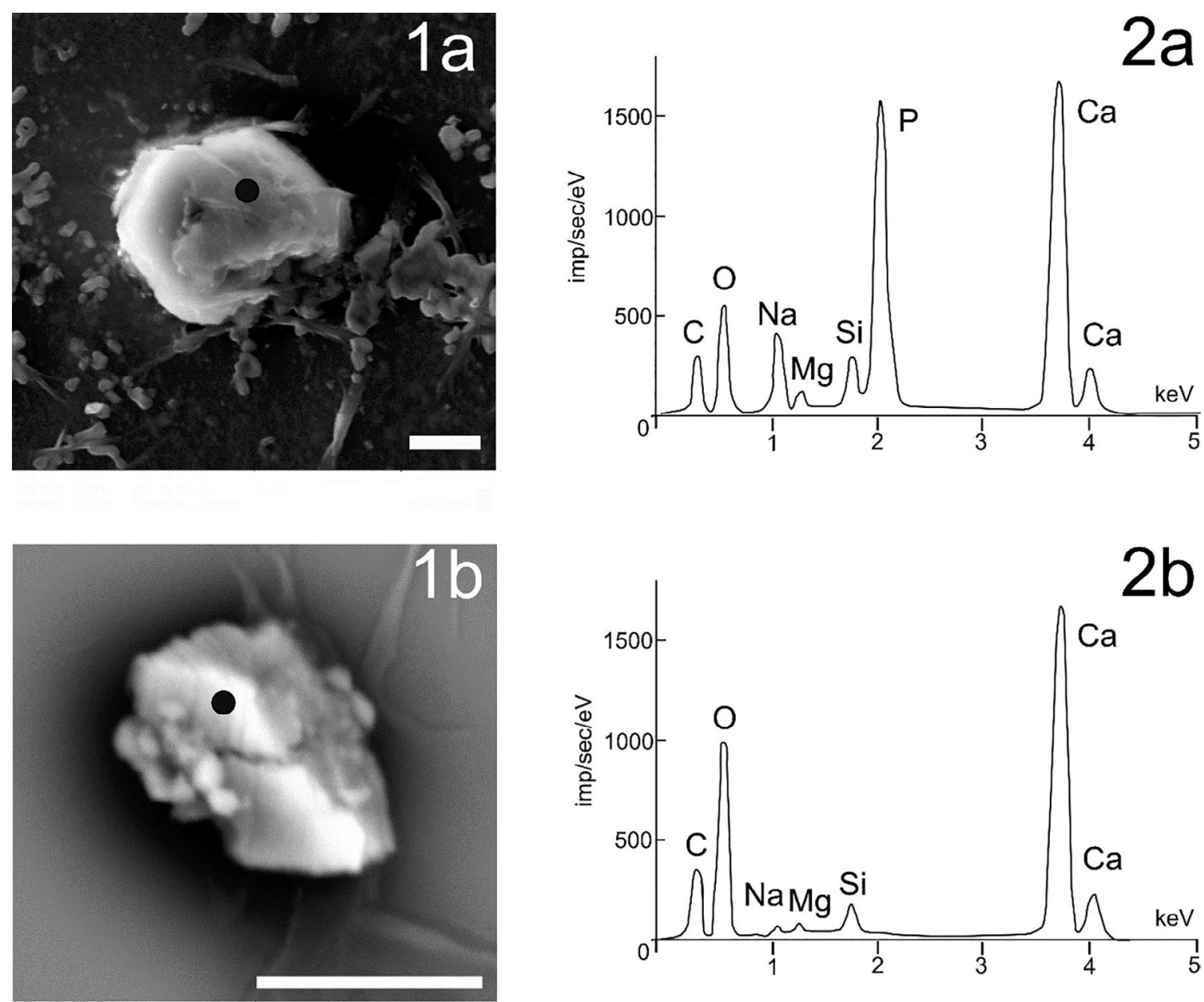

Fig. 3. Secondary electron (SE) images (1) and elemental energy dispersive spectra (2) of pineal gland concrements composed of apatite (a) and calcite (b). Dots indicate EDS measurement location. Scale bar is $5 \mu \mathrm{m}$

only by the "mulberry-like" structure with the size ca. 2-13 $\mathrm{mm}$.

\section{Discussion}

The reported findings give a first insight into the morphology, mineral and chemical properties of pineal calcified concretions in blue fox.

The brain sand is the one of the most intriguing structure in the pineal gland, which is able to form the brain sand due to the high calcium content and the high phosphate turnover compared to other tissues [Borell, Örström, 1947; Vígh et al., 1989]. However, the biological significance of pineal calcium concrements is still unknown.

We detected the presence of pineal acervuli in both juveniles and adults blue fox. However, previously Bulc et al. [2010] revealed the brain sand in the pineal of blue foxes aged 3 years, but not in those aged 7-8 months. The relevance of concretions to aging is still arguable; in general views their incidence and amount are believed to increase with age [Schmid, 1993; Mori et al., 2003;
Admassie, Mekonnen, 2009; Bulc et al., 2010] despite several irrelevant cases [Tapp, Huxley, 1972; Maślińska et al., 2010].

The calcified concrements were located in the parenchyma of distal part of the blue fox gland, in the capsule surrounding it and in the protruding septae. Our results are in agreement with data of Bulc et al. [2010], who also observed the concretions in the pineal capsule and parenchyma of blue fox. Other authors revealed the differences in structure of capsular concrements and of parenchymal ones. The first show clear concentric lamination, but the second have the globular structure. As the capsule and septae of the pineal are formed by the arachnoid and pia mater sheets of the meninges, the concrements of the capsule and septae are the example of meningeal calcification [Vígh et al., 1998]. Similarly, acervuli from the capsule in our study had laminated structure, but most of the concrements formed in the pineal parenchyma also had alternative layers of light- and dark-stained rings. Others were strongly dark-stained, and the third 


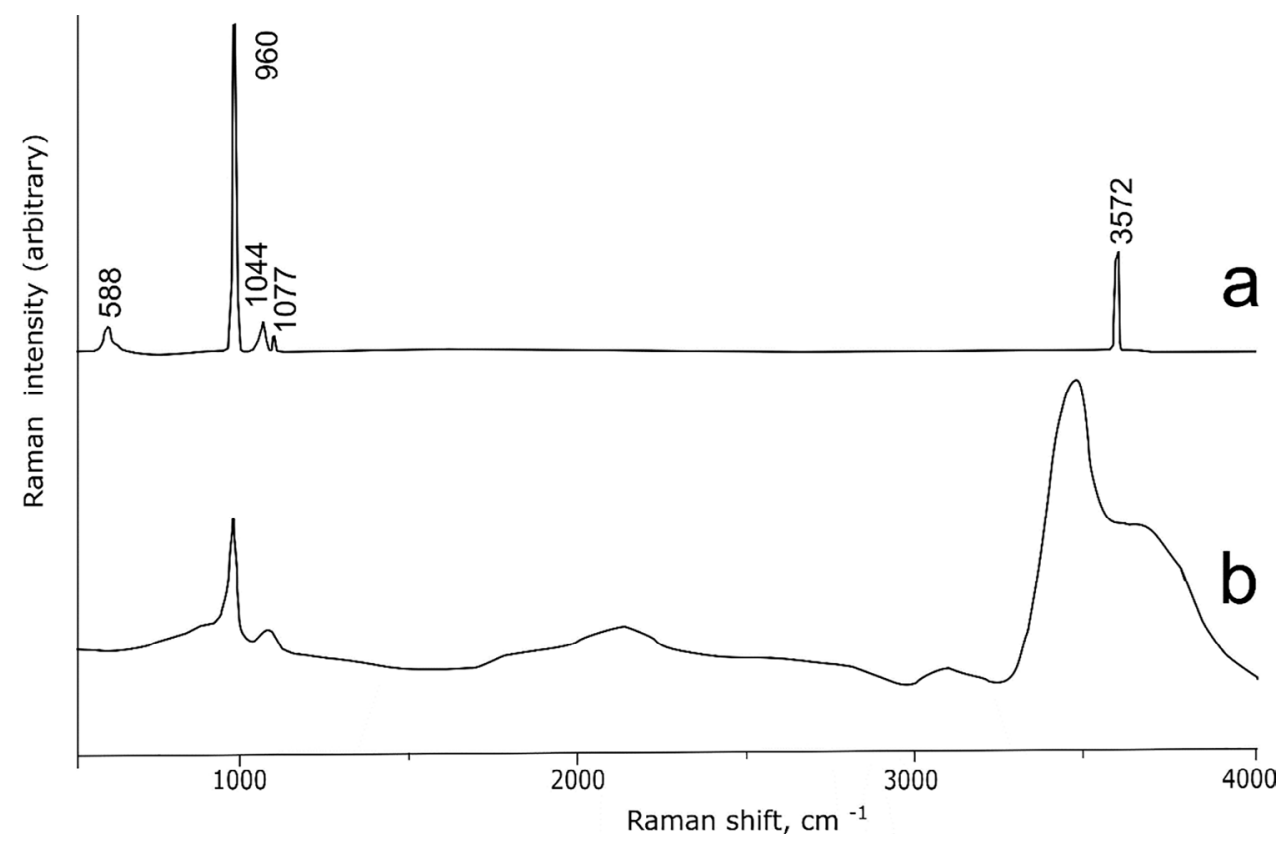

Fig. 4. Raman spectra of commercial hydroxylapatite (a) [modified after Pasteris et al., 2014] and hydroxylapatite from pineal gland concrements (b)

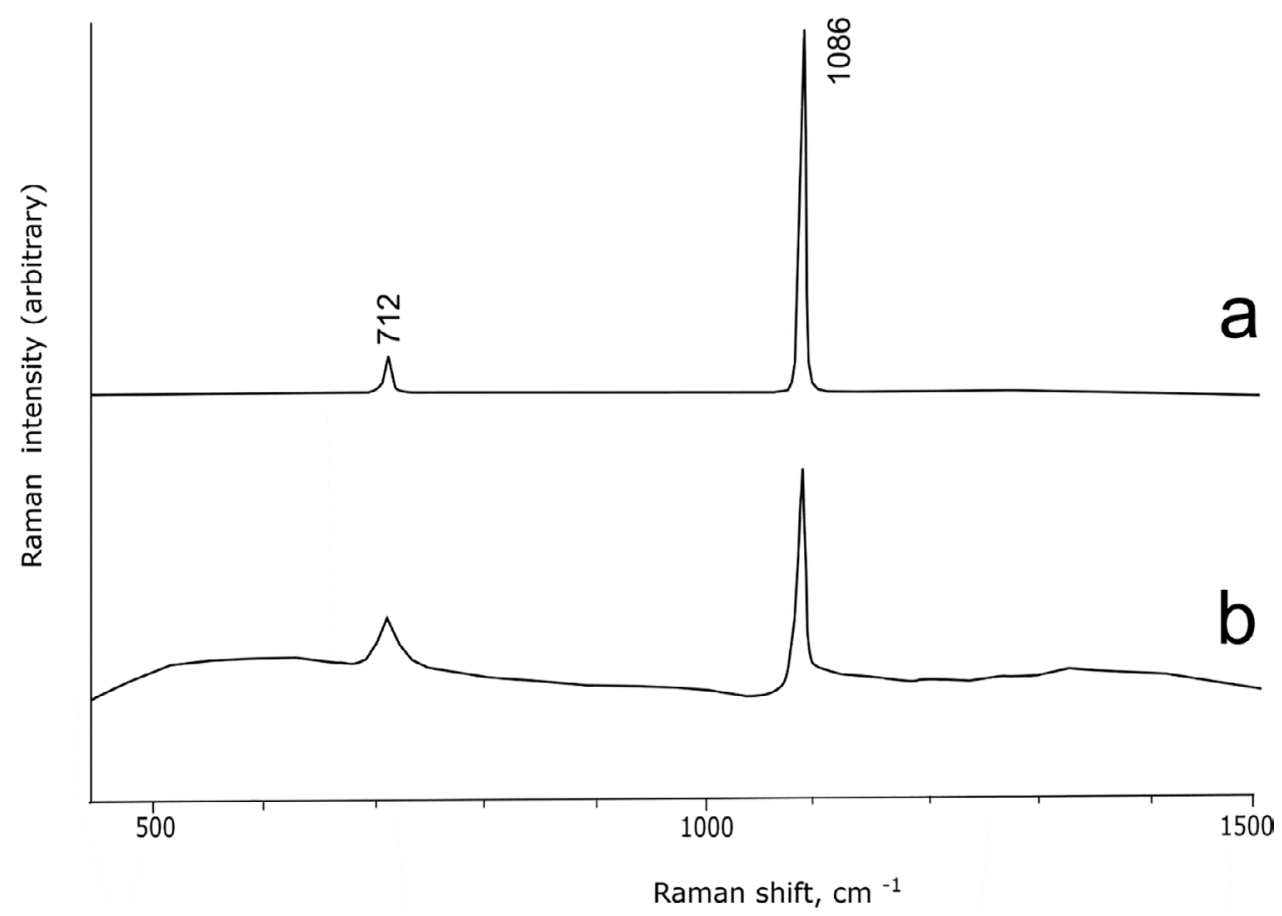

Fig. 5. Raman spectra of standard calcite sample (a) [RRUFF...] and calcite from pineal gland concrements (b)

group were light-stained and seemed to have hollow structure (in sections stained with H\&E). However, acervuli in samples stained according to the Masson-Goldner method were colored pink, light green or both, some of them had black rings, probably indicating differences in the composition of the concrements.

Although studies of the pineal gland have a long history, the mineral and chemical compositions of pineal calcified concretions have been predominately revealed in humans [Krstić, 1976; Bocchi, Valdre, 1993; Kodaka et al., 1994; Nakamura et al., 1995; Bacconier, Lang, 2004]. Such data for other mammalian species are scarce [Krstić, Golaz, 1977; Humbert, Pévet, 1995; Tofail et al., 2019]. Identification of the mineral composition of pineal calcified concretions is often challenging due to the small size and low bioavailability of these minerals. The SEM- 
EDS and Raman spectroscopy data obtained for the blue fox pineal indicate that pineal calcified concretions are made up of hydroxylapatite and calcite. Hydroxylapatite is characterized by the average $\mathrm{Ca} / \mathrm{P}$ ratio of 1.36 , which is similar to the composition variations in bioapatites [Frank-Kamenetskaya et al., 2011; Combes et al., 2016]. The identification of apatite in pineal concretions from blue fox is in agreement with the data reported by other researchers, who revealed that acervuli are mainly built up from hydroxyapatite [Bocchi, Valdre, 1993; Kodaka et al., 1994]. It should be emphasized that the morphology of the mulberry-like structure is similar for both blue fox pineal gland, as it is shown in the present study, and for human pineal gland [Kodaka et al., 1994]. However, hydroxylapatite in the calcified concretions from blue fox pineal gland occurred not only as mulberry-like structure, but also as elongate irregular-shaped particles with larger size of up to $25 \mathrm{~mm}$ (Fig. 2).

The SEM-EDS and Raman spectroscopy studies of calcified concretions from blue fox pineal gland showed that the additional mineral phase in the pineal gland was calcite. The data are in agreement with those obtained for the pineal gland of humans [Bacconier, Lang, 2004] and rats [Tofail et al., 2019]. However, other polymorphs of calcium carbonate, namely vaterite and aragonite, have also been recognized in the pineal gland of rats [Tofail et al., 2019]. Calcite in calcified concretions from blue fox pineal gland appeared as mulberry-like structure smaller that the elongate irregular-shaped hydroxyapatite particles.

The data concerning the mineral composition of calcium concretions in blue fox pineal are in agreement with those obtained by other researchers on rodent and human gland [Kodaka et al., 1994; Bacconier, Lang, 2004; Tofail et al., 2019]. The presence of two different mineral phases in the same organ is considered to be biologically significant [Bacconier, Lang, 2004; Tofail et al., 2019], but the mechanism of biomineralization remains unknown.

To date, there is no clear understanding of how and why calcium concretions form, but some mechanisms for their formation are suggested. Among them the impairment of $\mathrm{Ca}^{2+}$-dependent ATPase, changes in calcium channels, or a constant depolarization of pinealocytes calcium pomp leading to elimination of calcium out of the cell [Krstić, 1986]; death or degeneration of pinealocytes, resulting in an overall decrease in pineal activity [Schmid, 1993; Humbert, Pévet, 1995], and active participation of tryptase mast cells in the pineal calcification process as sites where it starts [Maślińska et al., 2010].
Overviewing the data available about pineal calcification, one can conclude that a multifactorial mechanism may be responsible for its formation [Vígh et al., 1998]. Moreover, the nature and crystallinity of the inorganic tissue of pineal concretions give reason to assume that the corpora arenacea is of a physiological rather than pathological ossification type, with characteristics between enamel and dentine, but with more marked analogies towards the latter [Bocchi, Valdre, 1993].

\section{Conclusions}

The reported findings give a first insight into the morphology, mineral and chemical composition of pineal calcium concrements in blue fox. The results suggest that the process of pineal gland mineralization is most likely not age-related. Our data concerning the location and mineral composition of calcium concretions in blue fox pineal gland are in agreement with those obtained by other researchers on rodent and human pineal glands. Calcified concretions were located in the capsule, protruding septae and parenchyma of pineal gland. Two morphological types of concrements were distinguished, including the mulberry-like and the irregular elongate structures. The acervuli of mulberry-like structure were made up of hydroxylapatite and calcite, and the irregular elongate aggregates were composed of hydroxylapatite only. The latter had not been previously recorded from calcified concretions from mammals. The data reported in this study contribute to the understanding of the calcification mechanism in the pineal gland.

The authors are grateful to Director of FSUE "Russian Sable" V. L. Shevyrkov, to Z. S. Ruchkina and to the Head of the Laboratory of Ecological Biochemistry of IB KarRC RAS S. A. Murzina for help in conducting the research. We also thank G. L. Kuranov for the methodology discussion.

The authors have no conflicts of interest that are directly relevant to the contents of this manuscript.

The study was carried out under state order (project № 0218-2019-0073).

\section{References}

Admassie D., Mekonnen A. Incidence of normal pineal and choroids plexus calcification on Brain CT (computerized tomography) at Tikur Anbessa Teaching Hospital Addis Ababa, Ethiopia. Ethiopian Med. J. 2009. Vol. 47. P. 55-60.

Baconnier S., Lang S. B. Calcite microcrystals in the pineal gland of the human brain: Second harmonic generators and possible piezoelectric transducers. IEEE $T$. Dielect. El. In. 2004. Vol. 11. P. 203-209. 
Bocchi G., Valdre G. Physical, chemical, and mineralogical characterization of carbonate-hydroxyapatite concretions of the human pineal gland. J. Inorganic Biochem. 1993. Vol. 49. P. 209-220.

Borell U., Örström $\AA$. The turnover of phosphate in the pineal body compared with that in other parts of the brain. Biochem. J. 1947. Vol. 41. P. 398-403.

Bulc M., Lewczuk B., PrusikM., GugolekA., Przybylska-Gornowicz $B$. Calcium concrements in the pineal gland of the Arctic fox (Vulpes lagopus) and their relationship to pinealocytes, glial cells and type I and III collagen fibers. Polish J. Vet. Sci. 2010. Vol. 13. P. 269-278.

Carden A., Morris M.D. Application of vibrational spectroscopy to the study of mineralized tissues (review). J. Biomed. Optics. 2000. Vol. 5. P. 259-268.

Combes C., Cazalbou S., Rey C. Apatite biominerals. Minerals. 2016. Vol. 6, no. 2. P. 34.

Frank-Kamenetskaya O., Kol'tsov A., Kuz'mina M., Zorina M., Poritskaya L. Ion substitutions and non-stoichiometry of carbonated apatite- $(\mathrm{CaOH})$ synthesised by precipitation and hydrothermal methods. J. Mol. Structure. 2011. Vol. 992. P. 9-18.

Gilbert P., Abrecht M., Frazer B. H. The organic-mineral interface in biominerals. Rev. Mineral. Geochem. 2005. Vol. 59. P. 157-185.

Humbert W., Pévet $P$. Permeability of the pineal gland of the rat to lanthanum: Significance of dark pinealocytes. J. Pineal Res. 1992. Vol. 12. P. 84-88.

Humbert $W$., Pévet $P$. Calcium concretions in the pineal gland of aged rats: an ultrastructural and microanalytical study of their biogenesis. Cell Tissue Res. 1995. Vol. 279. P. 565-573.

Karampas I. A., Kontoyannis C. G. Characterization of calcium phosphates mixtures. Vib. Spectrosc. 2013. Vol. 64. P. 126-133.

Kim J., Kim H.W., Chang S., Kim J.W., JeJ.H. Growth patterns for acervuli in human pineal gland. Sci. Rep. 2012. Vol. 2. P. 984-988.

Kodaka T., Mori R., Debari K., Yamada M. Scanning electron microscopy and electron probe microanalysis studies of human pineal concretions. Microscopy. 1994. Vol. 43. P. 307-317.

Krstić R. A combined scanning and transmission electron microscopic study and electron probe microanalysis of human pineal acervuli. Cell Tissue Res. 1976. Vol. 174. P. 129-137.

Krstić R. Pineal calcification: its mechanism and significance. J. Neural Transmis. Supp. 1986. Vol. 21. P. 415-432.

Krstić R., Golaz J. Ultrastructural and X-ray microprobe comparison of gerbil and human pineal acervuli. Experientia. 1977. Vol. 33. P. 507-508.

LewinskiA., Vaughan M. K., Champney T.H. Darkexposure increases the number of pineal concretions in male gerbils (Meriones unguiculatus). IRCS Med. Sci. 1983. Vol. 11. P. 977-978.

Luke J. Fluoride deposition in the aged human pineal gland. Caries Res. 2001. Vol. 35. P. 125-128.

Maślińska D., Laure-Kamionowska M., Deręgowski K., Maśliński S. Association of mast cells with calcification in the human pineal gland. Folia Neuropathol. 2010. Vol. 48. P. $276-282$.

Mori R., Kodaka T., Sano T. Preliminary report on the correlations among pineal concretions, prostatic cal- culi and age in human adult males. Anat. Sci Int. 2003 Vol. 78. P. $181-184$

Nakamura K. T., Nakahara H., Nakamura M., Tokioka T., Kiyomura $H$. Ultrastructure and x-ray microanalytical study of human pineal concretions. Ann. Anat. 1995. Vol. 177. P. 413-419.

Pasteris J.D., Yoder C. H., Wopenka B. Molecular water in nominally unhydrated carbonated hydroxylapatite: The key to a better understanding of bone mineral. Am. Miner. 2014. Vol. 99. P. 16-27.

RRUFF database of Raman spectroscopy, X-ray diffraction and chemistry of minerals. URL: https://rruff.info (accessed: 20.02.2021).

Schmid H. A. Decreased melatonin biosynthesis, calcium flux, pineal gland calcification and aging: a hypothetical framework. Gerontol. 1993. Vol. 39. P. 189-199.

Tan D. X., Xu B., ZhouX., ReiterR. J. Pineal calcification, melatonin production, aging, assocated health consequences and rejuvenation of the pineal gland. Molecules. 2018. Vol. 23. Art. 301. doi: 10.3390/ molecules23020301

Tapp E., HuxleyM. The histological appearance of the human pineal gland from puberty to old age. J. Pathol. 1972. Vol. 108. P. 137-144.

Thomas D. B., McGoverin C. M., Fordyce R. E., Frew R. D., Gordon K. C. Raman spectroscopy of fossil bioapatite - A proxy for diagenetic alteration of the oxygen isotope composition. Palaeogeogr. Palaeoclimatol. Palaeoecol. 2011. Vol. 310, no. 1-2. P. 62-70.

Timlin J. A., Carden A., Morris M. D. Chemical microstructure of cortical bone probed by Raman transects. App. Spectr. 1999. Vol. 53. P. 1429-1435.

Tofail S. A. M., Mouras R., McNamara K., PatykKazmierczak E., Geaney H., Zaworotko M., Ryan K. M., Soulimane T., Silien C., Kopáni M. Multimodal surface analyses of chemistry and structure of biominerals in rodent pineal gland concretions. Appl Surf. Sci. 2019. Vol. 469. P. 378-386.

Turgut A. T., KarakașH. M., ÖzsunarY., Altın L., Çeken K., Alıcıoğlu B., Sönmezi., Alparslan A., Yürümez B., Çelik T., Kazak E., Geyik P. Ö., Koşar U. Age-related changes in the incidence of pineal gland calcification in Turkey: A prospective multicenter CT study Pathophysiol. 2008. Vol. 15. P. 41-48.

Vígh B., Vigh-Teichmann I., Heinzeller T., Tutter I. Meningeal calcification of the rat pineal organ. Histochem. 1989. Vol. 91. P. 161-168.

Vígh B., Szél A., Debreceni K., Fejér Z., e Silva M. M., Vigh-Teichmann I. V. Comparative histology of pineal calcification. Histol. Histopathol. 1998. Vol. 13. P. 851-870.

Vollrath $L$. The pineal organ. Oksche A. and Vollrath L. (eds) Handbuch Der Mikroskopischen Anatomie Des Menschen vol 7. Springer, Berlin, Heidelberg, New York, 1981.

Whitehead M. T., OhC., RajuA., ChoudhriA. F. Physiologic pineal region, choroid plexus, and dural calcifications in the first decade of life. Am. J. Neuroradiol. 2015. Vol. 36 (3). P. 575-580. doi: 10.3174/ajnr. A4153

Zimmerman R. A., Bilaniuk L. T. Age-related incidence of pineal calcification detected by computed tomography. Radiol. 1982. Vol. 142. P. 659-662.

Received March 20, 2021 


\section{СВЕДЕНИЯ ОБ АВТОРАХ:}

\section{Калинина Светлана Николаевна}

заведующая лаб. экологической физиологии животных, к. б. н.

Институт биологии КарНЦ РАН,

Федеральный исследовательский центр

«Карельский научный центр РАН»

ул. Пушкинская, 11, Петрозаводск, Республика Карелия, Россия, 185910

эл. почта: cvetnick@yandex.ru

тел.: +79114241881

\section{Чаженгина Светлана Юрьевна}

старший научный сотрудник лаб. геохимии, четвертичной геологии и геоэкологии, к. г.-М. н.

Институт геологии КарНЦ РАН,

Федеральный исследовательский центр

«Карельский научный центр РАН»

ул. Пушкинская, 11, Петрозаводск, Республика Карелия, Россия, 185910

эл. почта: chazhengina@mail.ru

тел.: +79116601533

\section{Илюха Виктор Александрович}

директор ИБ КарНЦ РАН, главный научный сотрудник лаб. экологической физиологии животных, д. б. н.

Институт биологии КарНЦ РАН,

Федеральный исследовательский центр

«Карельский научный центр РАН»

ул. Пушкинская, 11, Петрозаводск, Республика Карелия Россия, 185910

эл. почта: ilyukha@bio.krc.karelia.ru

\section{Светов Сергей Анатольевич}

директор ИГ КарНЦ РАН, руководитель и главный

научный сотрудник лаб. геохимии, четвертичной

геологии и геоэкологии, д. г.-М. н., старший научный

сотрудник, проф.

Институт геологии КарНЦ РАН

Федеральный исследовательский центр

«Карельский научный центр РАН»

ул. Пушкинская, 11, Петрозаводск, Республика Карелия, Россия, 185910

эл. почта: ssvetov@krc.karelia.ru

\section{Хижкин Евгений Александрович}

старший научный сотрудник лаб. экологической

физиологии животных, к. б. н.

Институт биологии КарНЦ РАН,

Федеральный исследовательский центр

«Карельский научный центр РАН»

ул. Пушкинская, 11, Петрозаводск, Республика Карелия, Россия, 185910

эл. почта: hizhkin84@mail.ru

\section{CONTRIBUTORS:}

Kalinina, Svetlana

Institute of Biology, Karelian Research Centre,

Russian Academy of Sciences

11 Pushkinskaya St., 185910 Petrozavodsk, Karelia, Russia

e-mail: cvetnick@yandex.ru

tel.: +7911424188

\section{Chazhengina, Svetlana}

Institute of Geology, Karelian Research Centre,

Russian Academy of Sciences

11 Pushkinskaya St., 185910 Petrozavodsk, Karelia, Russia e-mail: chazhengina@mail.ru

tel.: +79116601533

\section{Ilyukha, Victor}

Institute of Biology, Karelian Research Centre,

Russian Academy of Sciences

11 Pushkinskaya St., 185910 Petrozavodsk, Karelia, Russia

e-mail: ilyukha@bio.krc.karelia.ru

\section{Svetov, Sergey}

Institute of Geology, Karelian Research Centre,

Russian Academy of Sciences

11 Pushkinskaya St., 185910 Petrozavodsk, Karelia, Russia e-mail: ssvetov@krc.karelia.ru

\section{Khizhkin, Evgeny}

Institute of Biology, Karelian Research Centre,

Russian Academy of Sciences

11 Pushkinskaya St., 185910 Petrozavodsk, Karelia, Russia e-mail: hizhkin84@mail.ru 